\title{
INTERNAL ROT DETECTION WITH THE USE OF LOW-FREQUENCY FLAW DETECTOR
}

\author{
Marek PROSKÓRNICKI, Grzegorz LIGUS ${ }^{1}$ \\ Opole University of Technology, Department of Mechanical Engineering, \\ Department of Environmental Engineering, Poland
}

\begin{abstract}
The issue of rot detection in standing timber or stocked wood is very important in forest management. Rot flaw detection used for that purpose is represented by invasive and non-invasive devices. Non-invasive devices are very accurate, but due to the cost and complicated operation they have not been applied on a large scale in forest management. Taking into account the practical needs of foresters a prototype of low-frequency flaw was developed. The principle of its operation is based on the difference in acoustic wave propagation in sound wood and wood with rot.
\end{abstract}

Keywords: internal rot, flaw detection methods, quality of the forests biotopes

\section{INTRODCTION}

The weakening condition of pine stands has been observed for a long time. One of the reasons has been the air pollution by $\mathrm{SO}_{2}$ and $\mathrm{NO}_{2}$ [6]. The reduction of the viability of the trees facilitates pathogenic fungi infections and finally can cause rot formation [4]. Rot is particularly detrimental because it has a significant impact on the quality of timber. This applies both to standing timber and wood in stakes on forest depots [3]. Consequently rot flaw detection becomes very important in forest management. One of the precursors of rot diagnosis was Gilwald [7]. Today's flaw detectors are much more advanced devices. They use non-invasive techniques, characterized by excellent diagnostic results. Unfortunately, they are expensive and difficult to use in

\footnotetext{
${ }^{1}$ Corresponding author: Opole University of Technology, Department of Mechanical Engineering, Department of Environmental Engineering, e-mail: g.ligus@ po.opole.pl, tel. tel. +48774498390
} 
forest terrain $[1,2,5]$. Accordingly, there is a need to develop simple-to-use devices to identify rot in wood.

\section{AUTHORS'OWN METHOD PROPOSAL}

On the basis of a lot of terrain work associated with quality control inspections and foresters' suggestions, requirements for apparatuses for internal rot detection were formulated. The following are the main recommendations of practitioners: small overall dimensions, low energy consumption, simple operation, clear interpretation of measurements (at two levels: the existence of rot in wood and the estimation of rot volume of fraction). The construction design of the author's own apparatus proposition is based on Mańka's method. It was assumed that if while tapping wood a forester is able to detect not only wood's emptiness, but also internal rot, there is a chance to replace metal object by acoustic propagator and carry out a noise analysis. In preliminary experiments the frequency of the acoustic wave propagated in the method by Mańka was established. Depending on the strength of hitting and diameter at breast height, frequency resulting for sound wood was recorded $(500 \mathrm{~Hz}, 650$ $\mathrm{Hz}$ and $850 \mathrm{~Hz}$ ). On the basis of these studies the device frequency range 450 $950 \mathrm{~Hz}$ was established (Fig. 1).

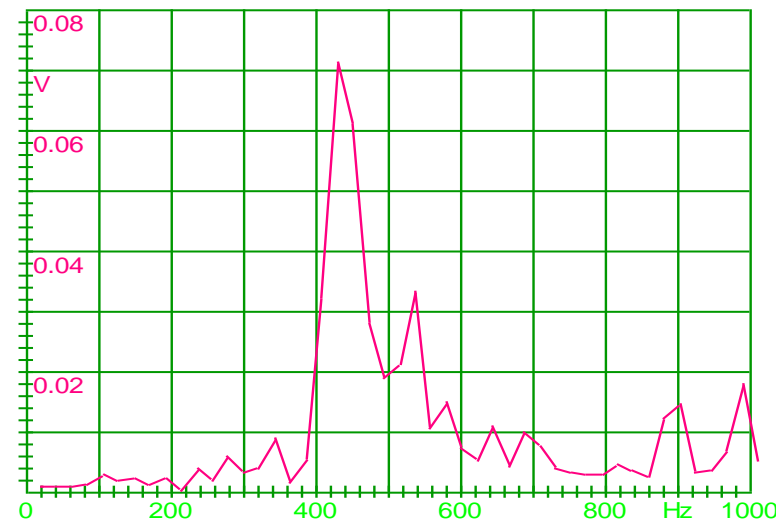

Fig. 1. Hammer test amplitude spectrum for Mańka's method (pine wood diameter $300 \mathrm{~mm}$, rot volume of fraction $35 \%$ )

The final principle of flaw detector operation is based on the following assumptions:

- acoustic wave propagation in sound wood is different from the propagation in wood with rot

- sound wood acoustic impedance is higher than rot wood acoustic impedance 
- there are differences in the intensity of acoustic power between sound wood and rot wood.

The device consists of two units: the transmitter (blue in Fig. 2) and the receiving-and-measuring unit (red in Fig. 2).

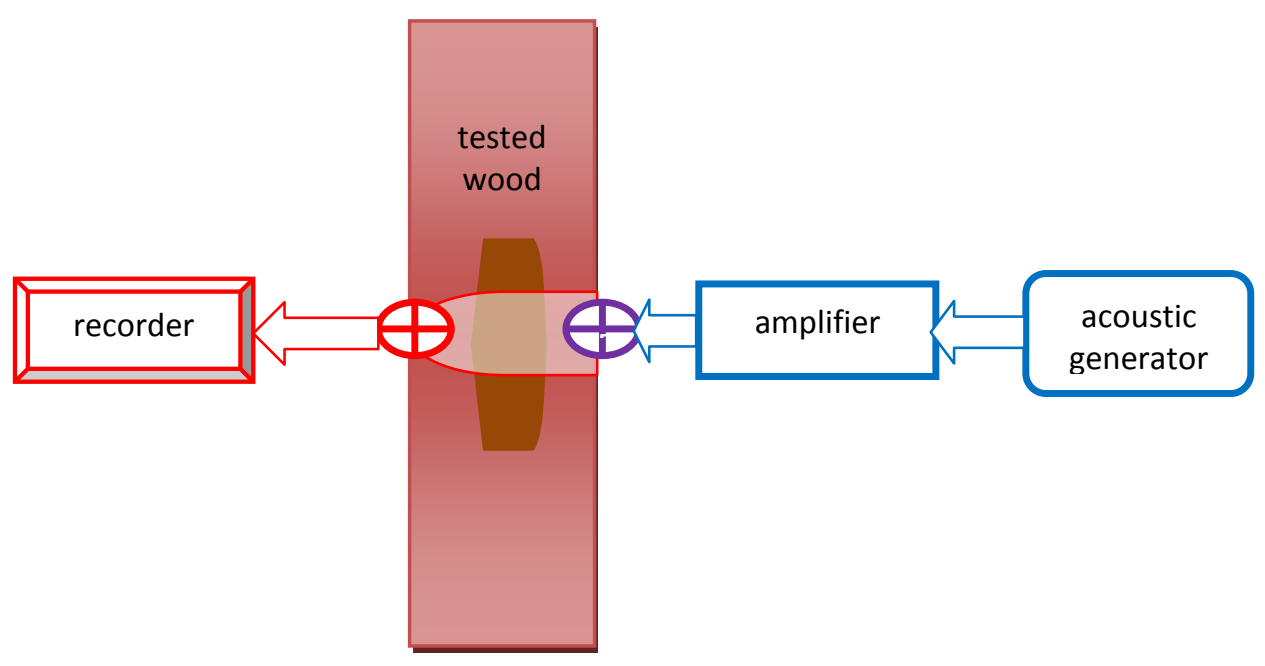

Fig. 2. Schematic diagram of the authors' own rot flaw detector

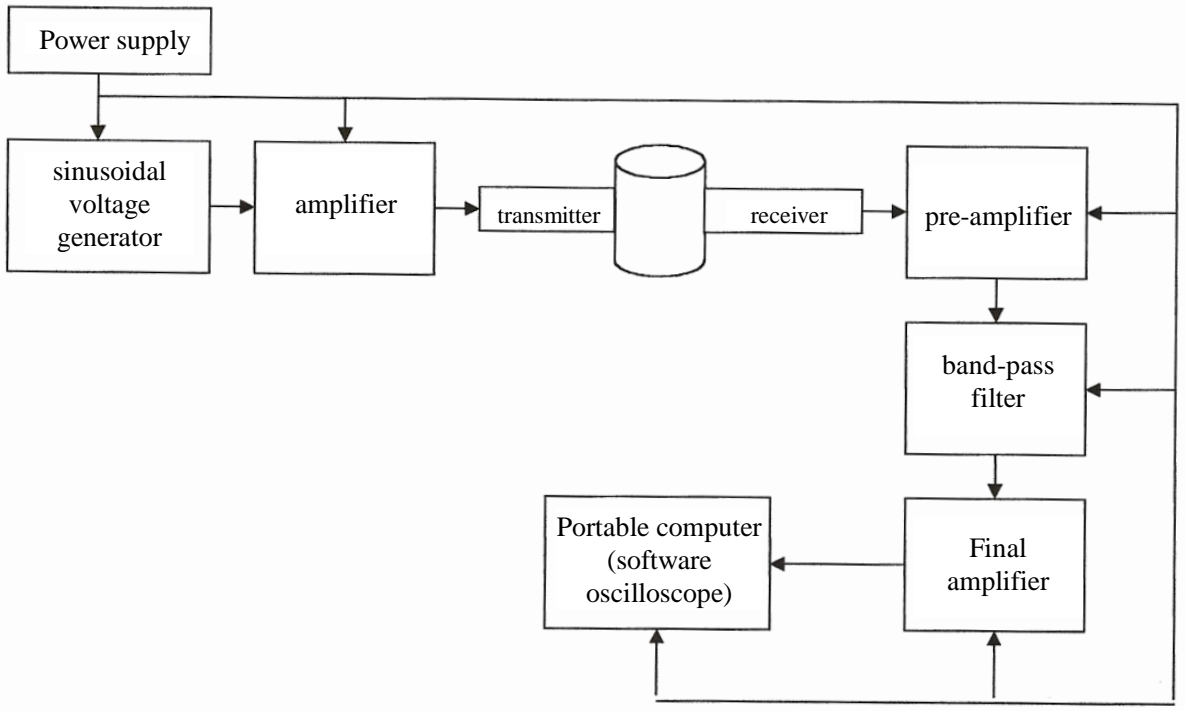

Fig. 3. Block diagram of the rot flaw detector 
The apparatus battery supply $(1.5 \mathrm{~V})$ makes it possible to use it in situ. The power supply is common to all the system units. Possible interactions between all the system units were eliminated by proper power supply filtration. As a source of signal a sinusoidal voltage generator was used. The generator with frequency ranges from 200 to $2000 \mathrm{~Hz}$ on the IL8038 chip was built. Sinusoidal signal obtained at the output is sent to an amplifier, which uses a TEA2025 chip (dual system, a bridge circuit, gain 50-75 dB). The transmitter has a headphone system and provides good transmission of selected frequencies. The receiver is a sensitive electret system, operating in the bands $10-10000 \mathrm{~Hz}$. The signal from the receiver is directed to the preamplifier (built into the TL082 chip) and then to the band-pass filter which consists of a high-pass filter and a low-pass filter in the Butterworth system. The signal from the output of the filter is transmitted to final amplifier which was built on the LM386 chip (gain of about $100 \mathrm{~dB}$ ). The output signal of the final amplifier is transmitted to the computer through audio line input, where it is analysed in a ZELSCOPE 1.0 software oscilloscope. The prototype device was built in an ebonite cuboid $(180 \times 90 \times 50 \mathrm{~mm})$ and connected to a portable computer (Fig. 4). Ultimately, the computer can be replaced by an analytical LCD module. The propagator and the acoustic signal sensor are placed in acoustic slots (diameters 40 and $20 \mathrm{~mm}$, depth of 15$20 \mathrm{~mm}$ ), on one measurement level, which is called the acoustic diameter (Fig. 5). Wave propagation takes place in an orthogonal direction to the fibre at a height of 1-1.3 m. Diagnostic analysis is based on the volume of the acoustic power measurement determined from the curve amplitude spectrum.

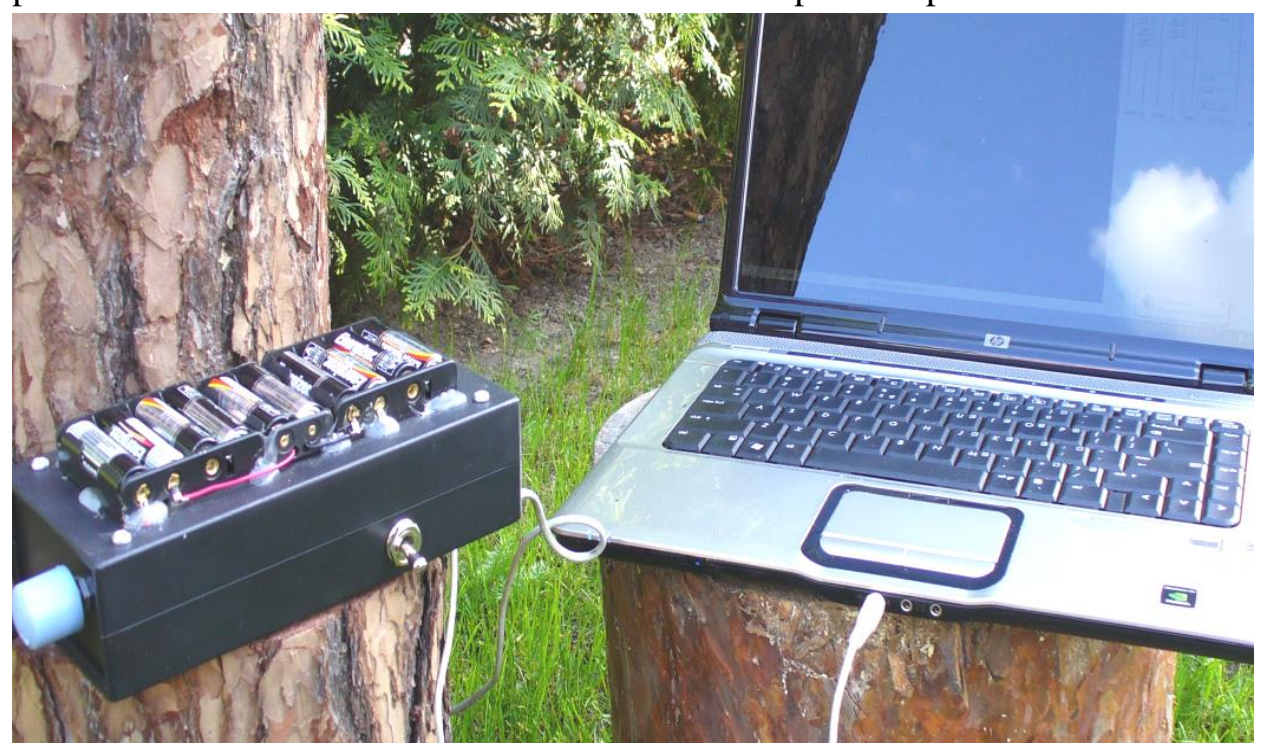

Fig. 4. Apparatus prepared for the measurement 
a)

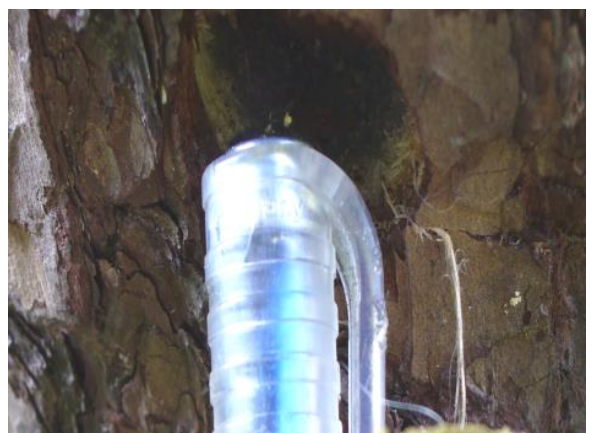

b)

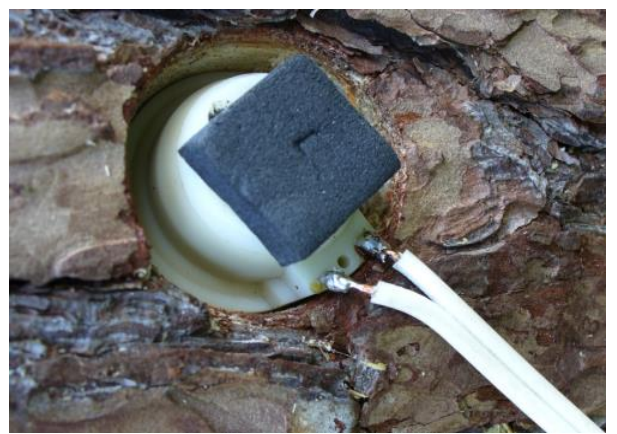

Fig. 5. Acoustic slots: a) receiving unit, b) transmitter with acoustic wave propagator

The full range of device frequency is within the range from 10 to $2000 \mathrm{~Hz}$. The first differences between the spectral waveforms of sound wood and wood with rot appear already at the frequency of $350 \mathrm{~Hz}$. A significant progression of waveforms change was registered in 450-850 Hz. Over this frequency the range of waveforms differences is much smaller (Fig. 6).

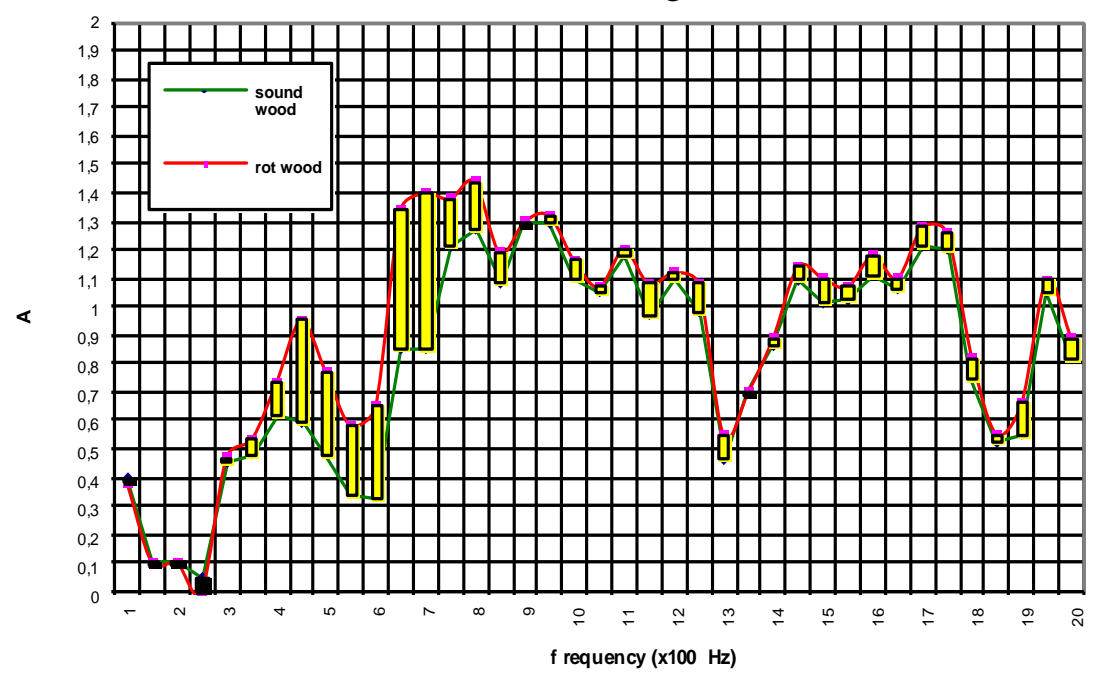

Fig. 6. Waveforms for sound wood and wood with rot (acoustic diameters $297 \mathrm{~mm}$, rot volume of fraction $35 \%$ )

The measurements were carried out on the pine wood samples obtained from clear-cuts and sanitation-cuts. The lengths of the wood samples ranged from 450 to $500 \mathrm{~mm}$. Tests on standing timber were carried out in the felling site area, and then verified by measurements in stacks. Particularly good results for the acoustic diameters of 250 to $350 \mathrm{~mm}$ were obtained (destructive rot with 
emptily). Fig. 7 shows a cross-section of a wood sample.

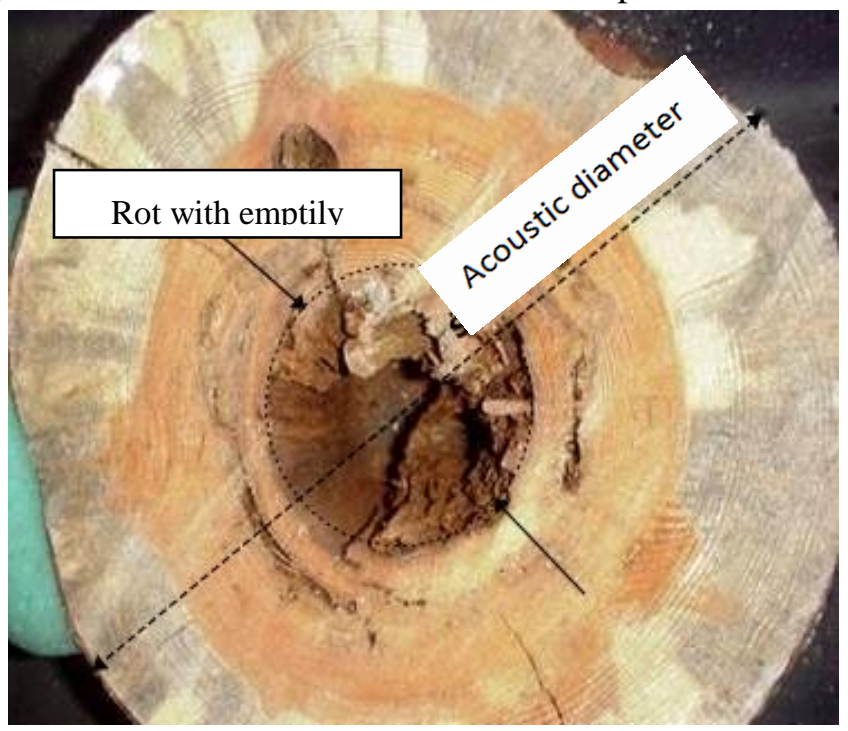

Fig. 7. Cross-sectional of wood with internal rot (sample with emptily)

The amplitude of the sinusoidal acoustic wave with the frequency $\mathrm{f}=650 \mathrm{~Hz}$, for the sound wood with a diameter of $367 \mathrm{~mm}$ has the value $0.75 \mathrm{~V}$. While for the wood with internal destructive rot (diameter $375 \mathrm{~mm}$ ) the value is $1.45 \mathrm{~V}$ (Fig. 8).

a)

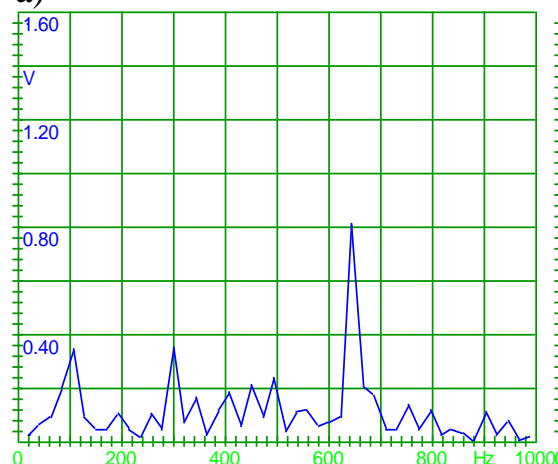

b)

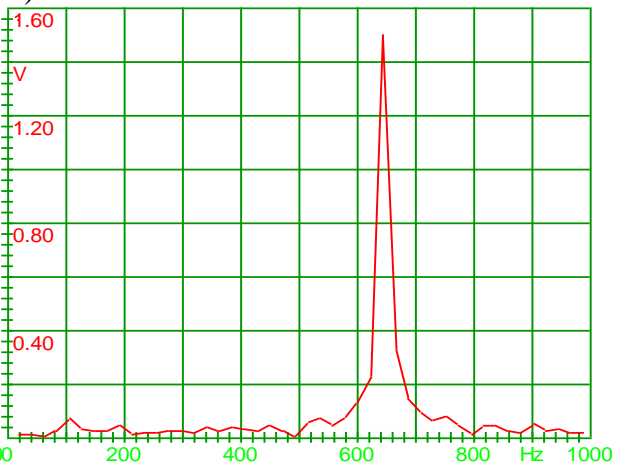

Fig. 8. The amplitude of the sinusoidal acoustic wave for $\mathrm{f}=650 \mathrm{~Hz}$ : a - sound wood, diameter $367 \mathrm{~mm}$; b - wood with internal rot, diameter $375 \mathrm{~mm}$ 
The curve amplitude spectrum in the full range of frequencies from 450 to 850 $\mathrm{Hz}$ was approximated. In this way the intensity of acoustic power was determined (Fig. 9). It has been found that the intensity of the acoustic power for sound wood is about $1.21 \mathrm{~W} / \mathrm{m}^{2}$, and for wood with destructive rot 3.04 $\mathrm{W} / \mathrm{m}^{2}$.

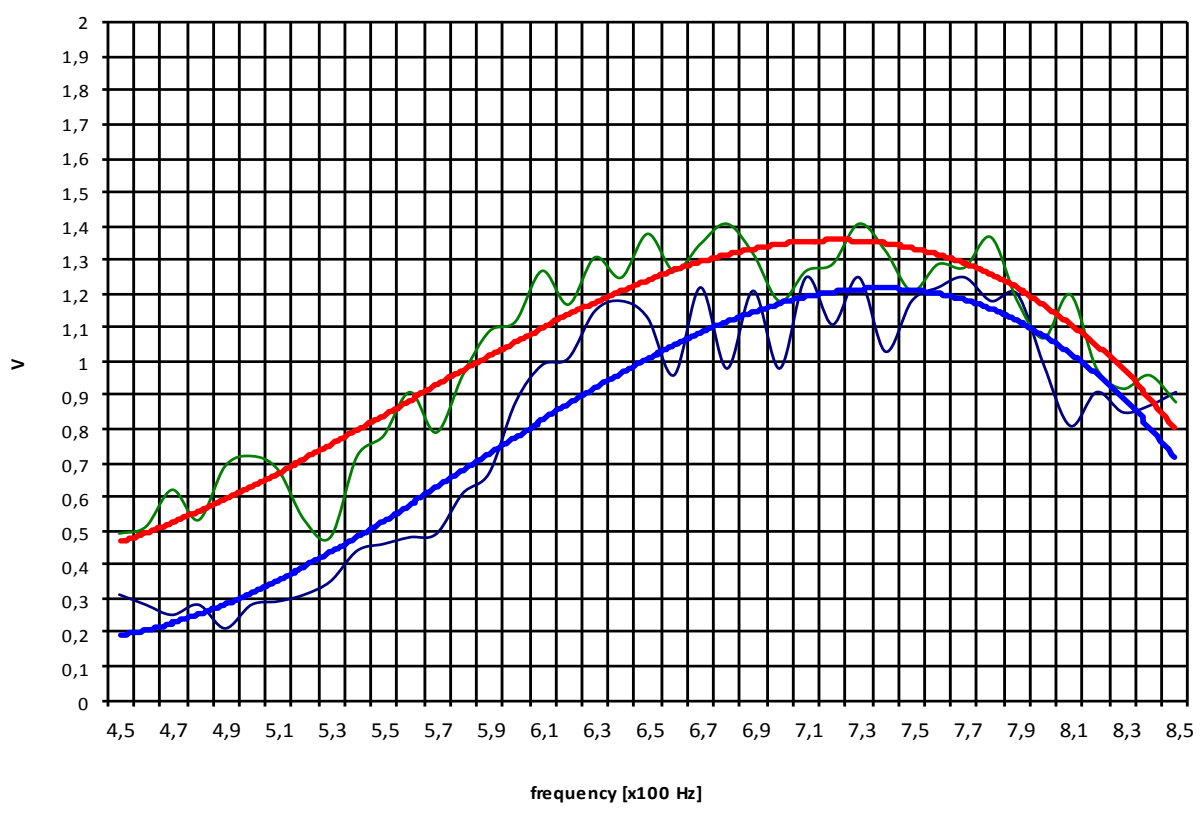

Fig. 9. Curve amplitude spectrum in the range of frequencies from 450 to $850 \mathrm{~Hz}$ (red curve - rot wood, blue curve - sound wood)

Further measurements showed a correlation between the intensity of the acoustic power and following parameters: acoustic diameter, rot volume of fraction, degree of the wood destruction. It was found that, in the frequency range from 650 to $850 \mathrm{~Hz}$ and acoustic diameters from 300 to $400 \mathrm{~mm}$, an increase in the rot volume of fraction caused also an increase of the intensity of acoustic power. The increase of the acoustic diameter, makes the difference decrease slightly. For diameters larger than $400 \mathrm{~mm}$ with a slight rot volume of fraction, these differences are within the margin of error $\left( \pm 0.25 \mathrm{~W} / \mathrm{m}^{2}\right)$. Standing timber tests showed similar differences (the intensity of acoustic power reduced by approximately 10\%) (Fig. 10). The proposed method used on 14 trees was verified by a quality control inspector. Clearly rot occurrence in the case of 12 trees was confirmed. 


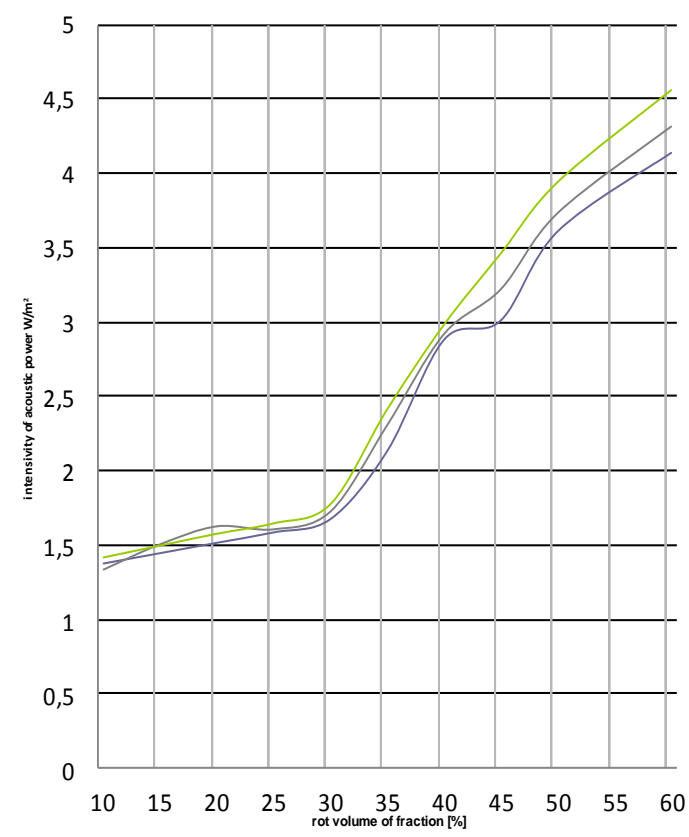

Fig. 10. The relationship of the rot volume of fraction and intensity of acoustic power for diameters from 300 to $400 \mathrm{~mm}$

\section{DISCUSSION OF RESULTS}

The apparatus operates in low-frequency. A significant power wave propagates in wood with rot, which has a very heterogeneous structure and thus different acoustic impedance. According to the Huygens' Principle, wave can be absorbed in part or completely. Assuming that a wave emitted in the wood is a beam energy flux, we may consider it the propagation of energy in a medium with variable impedance [9]. Sound wood impedance is $1960 \cdot 10^{3} \mathrm{~Pa} \cdot \mathrm{s} / \mathrm{m}$ (for atmospheric air impedance is $415 \mathrm{~Pa} \cdot \mathrm{s} / \mathrm{m}$ ), rot wood impedance calculated from data obtained in the experiments has a level of $(1470 \div 1660) 10^{3} \mathrm{~Pa} \cdot \mathrm{s} / \mathrm{m}$. Destructive rot impedance is therefore an unstable parameter, dependent on: the degree of wood degradation, decay mechanism humidity.

Acoustic impedance of wood with rot is smaller by about $15-25 \%$ than the acoustic impedance of sound wood. The smaller rot wood impedance may explain an internal structure of the rot. Destructive rot can be likened to a number of small plates, loosely adjoining to each other and sound wood. This means that there must be a unique transmission mechanism of an acoustic wave in wood with rot. To confirm this thesis an experiment was carried out. 


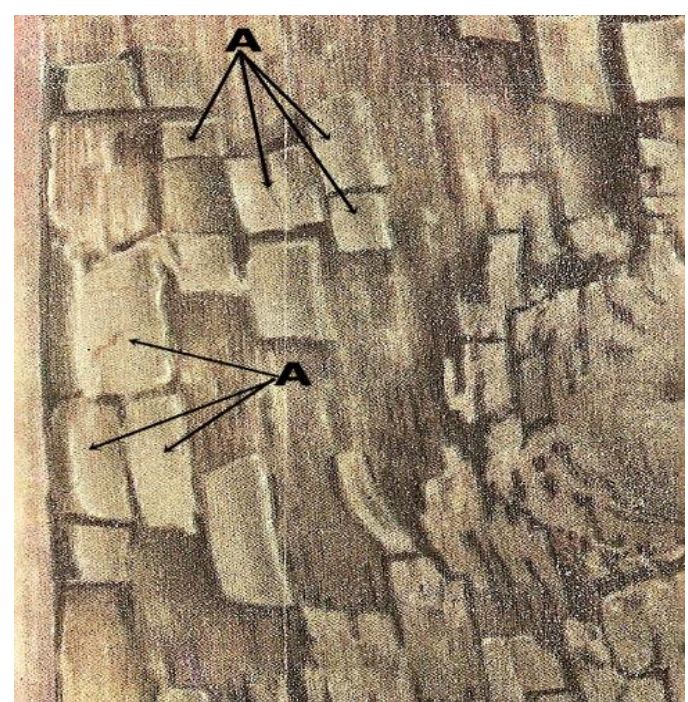

Fig. 11. Internal rot structure. Point A - agglomeration of "vibrating" plates [8]

Into internal rot in wood two metal rods were introduced on one level. On the first rod a mechanical frequency generator was placed, on the second rod an analogue frequency analyser in the range of 50 to $900 \mathrm{~Hz}$. The rods are introduced only in the structure of the rot. Drilled channels were isolated by synthetic rubber (Fig.12). Moisture of the sample was approximately 19\%. From 100 to $350 \mathrm{~Hz}$ vibration damping was significant (reached up to 55\%). In the range of $350-500 \mathrm{~Hz}$ vibration damping had already fallen to $33 \%$, while above $500 \mathrm{~Hz}$ was only in about $30 \%$.

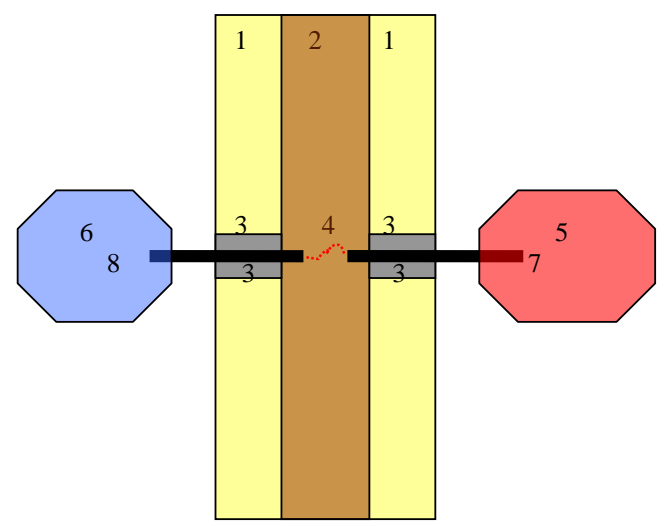

Fig. 12. Idea of the experiment: 1 - sound wood, 2 - destructive rot, 3 - vibration separator, 4 - vibration in the rot, 5 - mechanical frequency generator, 6 - analogue frequency analyser, 7 - transmitting rod, 8 - receiving rod 


\section{CONCLUSIONS}

The proposed apparatus for detecting internal rot gives satisfactory results for stocked wood. The use of the apparatus is limited by the range of measuring diameters (practically to $300-350 \mathrm{~mm}$ ). The advantage is a small size, low energy consumption and simple method of measurement. It is currently being developed to increase the power signal by replacing constant propagation by pulse propagation. This will increase the range of the measured diameter and affect differences in the intensity of the acoustic power in standing timber tests.

\section{REFERENCES}

1. Chomicz E.: Bezinwazyjne metody wykrywania defektów wewnętrznych pni drzew stojacych, Leśne Prace Badawcze, 2007/03, 117-121.

2. Dzbeński W., Wiktorski T.: Wykrywanie zgnilizny wewnatrz pni sosnowych drzew żywych za pomoca techniki ultradźwiękowej, monografia, „Technologia drewna - wczoraj i dziś”, SGGW, Warszawa, 2008.

3. Flaum H.: Użytkowanie lasu, Państwowe Wydawnictwo Rolnicze i Leśne, Warszawa, 1987.

4. Gawrońska G.: Wplyw zanieczyszczenia atmosfery na lasy Krainy Karpackiej, Rocznik Ochrony Środowiska, tom 2, 2000, 197-198.

5. Habermehl A. et al.: Zerstörungsfreier Nachweis von Kern-und Wundfäulen im Stamm stehender Bäume mit der Computer - Tomographie, Forstarchiv. 60, 1989, 239-245.

6. Stan uszkodzenia lasów w Polsce w 2007 roku na podstawie badań monitoringowych, Instytut Badawczy Leśnictwa, Biblioteka Monitoringu Środowiska, Sękocin Stary, 2008.

7. Laurow Z., Kubiak M.: Surowiec drzewny, Fundacja Rozwój SGGW Warszawa, 1994, 356-377.

8. Wady Drewna PN 66/D-01000, norma polska, Polski Komitet Normalizacyjny.

9. Weyna S.: Rozpływ energii akustycznych źródel rzeczywistych, Wydawnictwa Naukowo-Techniczne, Warszawa, 2005. 


\title{
WYKRYWANIE MURSZU WEWNĘTRZNEGO ZA POMOCĄ DEFEKTOSKOPU NISKOCZESTOTLIWOŚCIOWEGO
}

\begin{abstract}
Streszczenie
Zagadnienie wykrywania drewna zmurszałego $w$ drewnie drzew na pniu, w mygłach czy też na składach leśnych ma istotne znaczenie w gospodarce surowcem drzewnym. Wykorzystywana do tego celu defektoskopia murszowa jest reprezentowana przez liczną grupę urządzeń pracujących $\mathrm{w}$ technikach inwazyjnych i bezinwazyjnych. Urządzenia bezinwazyjne są bardzo dokładne ale ze względu na koszty i skomplikowaną obsługę nie znalazły zastosowania na wielką skalę w gospodarstwach leśnych. Biorąc pod uwagę potrzeby praktyczne służby leśnej, opracowano prototyp defektoskopu niskoczęstotliwościowego. Zasada działania urządzenia opiera się na różnicy w propagacji fali akustycznej w drewnie zmurszałym i zdrowym.
\end{abstract}

Słowa kluczowe: drewno zmurszałe, defektoskopia murszowa, gospodarstwa leśne

Editor received the manuscript: 09.04.2013 